\title{
Peningkatan Kemampuan Guru Produktif dalam Melaksanakan Pembelajaran Teaching Factory Melalui Workshop di SMK Negeri 7 Palu
}

\author{
Improving the Ability of Productive Teachers in Implementing Teaching Factory \\ Learning Through Workshops at SMK Negeri 7 Palu
}

\author{
Ashar* \\ SMKN 7 Palu, Jl. Komodo No. 78 Talise \\ *e-mail: asharnurdin008@gmail.com.id
}

\begin{tabular}{l}
\hline Article Info \\
\hline Article History: \\
Received: 27 Mei 2021 \\
Accepted: 30 Mei 2021 \\
Published: 31 Mei 2021 \\
Keywords: \\
Teaching Factory \\
Workshop \\
Kemampuan \\
\end{tabular}

\begin{abstract}
The motivation for this study was the low ability of productive teachers to carry out the learning process utilizing the Teaching Factory learning model at SMK Negeri 7 Palu. The teaching learning approach is appropriate for use in SMK since it produces graduates who are competent and ready to work. The purpose of this project is to use a workshop to increase the ability of productive teachers to apply learning using the Teaching Factory approach. The focus of this study is a successful teacher at SMK Negeri 7 Palu, which has a total of 12 students. This school action research was conducted in two cycles, with each cycle going through the planning, implementation, observation, and reflection stages. Data in cycle II increased with an average of 94 (A) and $91.67 \%$ completeness percentage. As a result of the training, productive teachers at SMK Negeri 7 Palu will be better able to execute Teaching Factory learning.
\end{abstract}

\section{PENDAHULUAN}

Sekolah sebagai lembaga pendidikan mempunyai tujuan untuk mengembangkan semua potensi yang dimiliki manusia yaitu, mulai dari tahapan kognisi, yakni pengetahuan dan pemahaman siswa terhadap ajaran agama dan pengetahuan umum, untuk selanjutnya dilanjutkan dengan tahapan afeksi, yaitu terjadinya proses internalisasi ajaran, nilai agama dan pengetahuan ke dalam diri siswa, dalam arti menghayati dan menyakininya. Salah satu komponen yang ada dalam sekolah adalah guru. Guru adalah pendidik yang menjadi tokoh, panutan dan identifikasi bagi peserta didik dan lingkungannya. Sesuai dengan Undang-undang guru dan dosen, ada tujuh tugas utama guru yaitu mendidik, mengajar, membimbing, mengarahkan, melatih, menilai dan mengevaluasi. Seorang guru dituntut memiliki kompetensi yang akan mendukung dalam melaksanakan tugas pokoknya. Salah satu tugas guru dalam melaksankan pembebelajaran adalah guru harus mampu membuat perencanaan dan pelaksanaan pembelajaran dengan baik dan benar sesuai kurikulum yang berlaku. Pelaksanaan pembelajaran juga mengandung unsur interaktif, inspiratif, menantang, menyenangkan serta membangun minat, kreatifitas peserta didik sehingga menciptakan pembelajaran yang bermakna. Sebagai seorang guru yang profesional hendaknya dapat memilih dan menerapkan metode yang efektif agar materi yang di pelajari oleh siswa dapat di pahami dengan baik. Jika perlu guru harus mampu melakukan pembelajaran mengunakan model pembelajaran yang bervariasi untuk mendapatkan hasil yang maksimal. Untuk itu guru harus mempunyai kreativitas dan inovasi baru dalam meningkatkan kemampuan dan teknik mengajarnya. Kemampuan teknik mengajar akan sangat berguna untuk membantu siswa mencapai tingkat ketuntasan belajar yang diharapkan

Pemilihan pendekatan pembelajaran, strategi pembelajaran, metode, teknik dan model pembelajaran yang tepat sangat mempengaruhi keberhasilan dalam pembelajaran. Sebagai guru, khususnya di SMK yang menitikberatkan pada peningkatan kompetensi siswa baik kognitif, afektif maupun psikomotoriknya. Sehingga ketika siswa lulus dari SMK memilki kemampuan yang dapat digunakan secara mandiri 
maupun diterapkan diindustri. Sehingga guru produktif SMK harus mampu melaksanakan pembelajaran secara maksimal.

Peran guru sangat penting dalam pengembangan pembelajaran. Dalam kegiatan belajar mengajar disekolah, guru yang menentukan apa aktivitas yang dapat dilakukan peserta didik sesuai pertumbuhan dan perkembangannya. Guru mengarahan dan menumbuhkan minat anak untuk mengikuti pembelajaran dikelas. Namun banyak ditemukan bahwa ada guru yang penguasaan suatu materi baik tetapi ketika melaksanakan kegiatan pembelajaran tidak dapat maksimal [1]. Hal itu terjadi karena kegiatan tersebut tidak didasarkan pada model pembelajaran tertentu sehingga hasil belajar yang diperoleh siswa rendah. Timbul pertanyaan apakah mungkin dikembangkan suatu model pembelajaran yang sederhana, sistematik, bermakna dan dapat digunakan oleh para guru sebagai dasar untuk melaksanakan kegiatan pembelajaran dengan baik sehingga dapat membantu meningkatkan motivasi berprestasi dan hasil belajar [2].

Model pembelajaran teaching factory merupakan salah satu model pembelajaran yang dapat diterapkan di SMK. Penerapan model pembelajaran teaching factory yang mana suasana pembelajarannya dirancang seperti keadaan dunia kerja yang sebenarnya [3]. Tujuan dari Teaching factory itu sendiri mengusahakan kegiatan memberikan pembelajaran kepada siswa harus lebih dari sekedar memberikan materi yang ada dalam buku ajar [4]. Melalui teaching factory, siswa akan mempraktikan tidak hanya keterampilan dalam pembelajaran, siswa juga belajar untuk bekerja secara kelompok, akan melatih diri siswa dalam berkomunikasi dengan orang lain serta mendapatkan pengalaman nyata dan berlatih melaksanakan pekerjaan untuk mempersiapkan dirinya ketika memasuki dunia kerja. Program teaching factory saat ini merupakan terobosan baru bagi dunia pendidikan kejuruan karena mampu menciptakan lulusan SMK yang berkompetensi dan siap kerja sesuai tuntutan dunia kerja [5].

Salah satu metode yang dapat diterapkan untuk meningkatkan kemampuan guru dalam melaksanakan pembelajaran adalah melalui workshop. Menurut Gomes [6] bahwa workshop adalah setiap usaha untuk memperbaiki prestasi kerja pada suatu pekerjaan tertentu yang sedang menjadi tanggung jawabnya. Workshop harus dirancang untuk mewujudkan tujuan-tujuan organisasi, yang pada waktu bersamaan juga mewujudkan tujuan-tujuan para pekerja secara perorangan. Melatih didefinisikan dengan membiasakan orang atau makhluk hidup agar mampu melakukan sesuatu. Proses membiaskan sangat identik dengan mengubah perilaku, sedangkan mampu melakukan sesuatu sama artinya dengan pengubahan kinerja untuk mencapai tujuan.

Kenyataan dilapangan masih banyak guru produktif di SMK Negeri 7 Palu memiliki kemampuan yang rendah dalam melaksanakan model pembelajaran teaching factory. Berdasarkan hasil observasi awala dari 12 orang guru produktif di SMK negeri 7 Palu baru 25\% yang dapat melaksanakan pembelajaran teaching factory dengan baik.
Hal tersebut disebabkan karena masih rendahnya kemauan guru dalam membuat persiapan pembelajaran yang baik dan buku-buku petunjuk cara melaksanakan pembelajaran teaching factory masih terbatas. Tentu saja hal ini akan mempengaruhi kualitas pembelajaran di SMK Negeri 7 Palu, sebagai salah satu Sekolah kejuruan yang harus mencetak sumber daya manusia yang siap pakai dalam dunia industri. Hal ini tidak dapat dibiarkan terus menerus karena akan mempengaruhi mutu pendidikan di SMK Negeri 7 Palu.

Penelitian terdahulu yang dilakukan oleh Sudiati [7] menyatakan bahwa kegiatan workshop memberi dampak positif terhadap kemampuan guru. Penelitian terdahulu yang lain juga dilakukan oleh Osnal dkk [8] menyatakan bahwa kemampuan guru kelas di KKG Gusus 02 Kecamatan Sumber Malangmengalami peningkatan. Penelitian yang dilakukan ini bertujuan untuk mengetahui kemampuan guru-guru produktif SMK Negeri 7 Palu dalam melaksanakan proses pembelajaran menggunakan model Teaching Factory melalui workshop.

\section{METODE}

Penelitian yang dilakukan ini termasuk jenis penelitian tindakan sekolah (school action research). Penelitian tindakan ini terfokus pada penelitian tindakan sekolah sebagai upaya memperbaiki proses pembelajaran yang dihadapi oleh guru. Penelitian yang dilakukan mengikuti model penelitian yang diberikan oleh Depdiknas., yang langkah-langkahnya dapat dilihat pada gambar berikut.

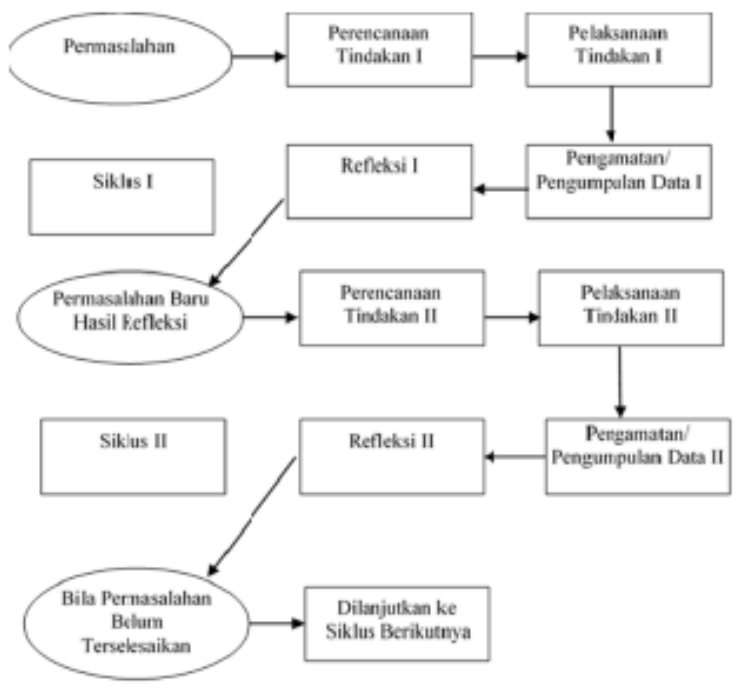

Gambar 1. Desain Penelitian Model Depdiknas (Depdiknas, 2009)

Penelitian Tindakan Sekolah (PTS) dilaksanakan di SMK Negeri 7 Palu yang beralamat di Jalan Komodo Talise, Palu. Subjek peneltian ini adalah 12 orang guru produktif yang mengajar di SMK Negeri 7 Palu. Jenis data dalam penelitian ini adalah data kuantitatif dan data kualitatif. Prosedur yang dilakukan mengikuti rancangan siklus yaitu dari perencanaan, pelaksanaan, observasi dan refleksi. 


\section{Prosedur Penelitian}

\section{Siklus I}

1) Perencanaan Tindakan. Berangkat dari hasil observasi awal yaitu mengetahui kelemahan-kelemahan guru dalam melaksanakan proses pembelajaran maka dibuatlah perencanaan tindakan siklus I. Dalam perencanaan ini, peneliti menyusun proposal. Perencanaan tindakan yang dilakukan antara lain menetapkan langkah-langkah yang diikuti dalam Teaching Factory, metode yang dipakai untuk mengumpulkan data, menyusun instrument berupa pedoman observasi.

2) Pelaksanaan Tindakan. Dalam tindakan ini dilakukan penyiapan pertemuan dengan guru-guru produktif, berdiskusi, bertanya jawab dilanjutkan dengan mengamati proses pembelajaran. Pengamatan pada proses pembelajaran dilakukan sewaktu guru melakukan pembelajaran dikelas. Setelah observasi dikelas, dilanjutkan dengan pertemuan balikan. Pada pertemuan ini guru-guru diajak bertanya jawab tentang apa yang telah mereka lakukan di kelas dan selnajutnya diberikan pembinaan-pembinaan

3) Pengamatan/Pengumpulan Data. Pengamatan yang dilakukan adalah mengamati apakah guru produktif telah mampu melaksnakan proses pembelajaran Teaching Factory. Mengamati apa yang menjadi kekurangan yang ada pada proses yang dilalukan, mencatat reaksi-reaksi mereka, mengecek apakah pelaksanaan proses pembelajaran Teaching Factory sydah berjalan dengan benar serta memberikan penilaian terhadap kemampuan guru produktif.

4) Refleksi. Dilaksanakan dengan cara membuat analisis kelemahan-kelemahan dari pelaksanaan tindakan sesuai arti refleksi, selanjutnya melakukan analisis, dan hasil analisis akan dipakai untuk menentukan strategi selanjutnya yang akan dilakukan pada siklus II. Untuk data kuantitatif ditampilkan dalam bentuk tabel dan grafik setelah mencari rata-rata, median dan modus.

\section{Siklus II}

1) Perencanaan Tindakan. Berdasarkan hasil refleksi siklus I maka itu menjadi dasar dalam merencakan siklus II. Merencanakan pembinaan agar mereka tidak grogi nantinya pada saat melaksanakan proses pembelajaran.

2) Pelaksanaan Tindakan. Kegiatan workshop lebih digiatkan lagi dan diintesifkan agar guru-guru produktif lebih memahami penerapan pembelajaran teaching factory dengan benar dan guru tidak mendominasi dalam proses pembelajaran.

3) Pengamatan. Pengamatan yang dialkukan yaitu pengamatan terhadap apa yang mampu mereka lakukan, apa yang tidak mampu, mencatat reaksi-reaksi yang ada, mengamati unjuk kerja guru produktif, melihat hasilhasil yang sudah dicapai dan memberi penilaian.
4) Refleksi. Refleksi II dilakukan dilakukan dengan langkah yang sama dengan di siklus I yaitu membuat analisis kelemahan dan kekuatan, kekurangan dan kelebihan kemampuan guru-guru melaksanakan proses pembelajaran. Mengecek kemajuan-kemajuan yang telah dilaksanakan, memberi pertimbangan, komentar, mencek perubahan perubahan yang telah dibuat. Melakukan analisis deskriptif data kuantitatif seperti cara yang sudah dijelaskan di siklus I.

Indikator keberhasilan dalam penelitian ini adalah meningkatnya kemampuan guru melaksanakan proses pembelajaran dari awal ke siklus I dan siklus II. Pada siklus I dan siklus II kemampuan guru diharapkan sudah mencapai nilai A $(91$ - 100) dengan ketuntasan minimal $80 \%$.

\section{HASIL DAN PEMBAHASAN}

\section{Hasil Penelitian}

Observasi awal yang dilakukan terhadap guru-guru produktif di SMK Negeri 7 Palu masih belum menggunakan model pembelajaran Teaching Factory. Dalam proses pembelajaran yang dilaksanakan yaitu guru hanya memberikan tugas sesuai contoh yang diberikan dan memberi motivasi-motivasi pada siswa. Dengan cara tersebut menandakan guru belum maksimal artinya kemampuan guru masih rendah dalam melaksanakan pembelajaran yaitu baru mencapai rata-rata $74(\mathrm{C})$ dengan ketuntasan $0 \%$.

Pada siklus I dilaksanakan tindakan sesuai dengan perencanaan siklus I yaitu menyiapkan semua perangkat untuk dipakai menejelaskan model Teaching factory, menyiapkan peraturan-peraturan yang berhubungan dengan model Teaching Factory dan meyiapkan pelaksanaan workshop. Proses workshop dilakukan dengan menjelaskan proses pembelajaran menggunakan Teaching Factory. Berkonsultasi dengan guru-guru produktif terlebih dahulu tentang kemampuan mereka. Mengingatkan agar guru-guru produktif tidak gugup dalam melaksnakan pembelajaran serta memberikan bimbingan, motivasi agar proses dilakukan dengan benar.

Berdasarkan hasil pengamatan pada siklus I, diperoleh data sebagai berikut :

Tabel 1. Hasil Penilaian Kemampuan Guru melaksanakan Pembelajaran Teaching factory siklus I

\begin{tabular}{llc}
\hline No & \multicolumn{1}{c}{ Keterangan } & Nilai \\
\hline 1 & Jumlah Nilai & 1025 \\
2 & Nilai rata-rata/kuantitatif & 86 \\
3 & Nilai Kualitatif & B \\
4 & Ketuntasan & 91 \\
5 & Guru yang tuntas & 5 \\
6 & Guru yang belum tuntas & 7 \\
7 & Persentase ketuntasan & $41,7 \%$ \\
\hline
\end{tabular}


Data kelas Interval hasil penilaian kemampuan guru produktif melaksanakan pembelajaran teaching factory dapat dilihat pada tabel dibawah ini.

Tabel 2. Data kelas interval siklus I

\begin{tabular}{ccccc}
\hline No & Interval & $\begin{array}{c}\text { Nilai } \\
\text { Tengah }\end{array}$ & $\begin{array}{c}\text { Frekuensi } \\
\text { Absolut }\end{array}$ & $\begin{array}{c}\text { Frekuensi } \\
\text { Relatif }\end{array}$ \\
\hline 1 & $76-80$ & 78 & 2 & 16,67 \\
2 & $81-85$ & 83 & 3 & 25 \\
3 & $86-90$ & 88 & 2 & 16,67 \\
4 & $91-96$ & 93,5 & 5 & 41,67 \\
& Total & & $\mathbf{1 2}$ & $\mathbf{1 0 0}$ \\
\hline
\end{tabular}

Data diatas dapat digambarkan dengan grafik histogram dibawah ini.

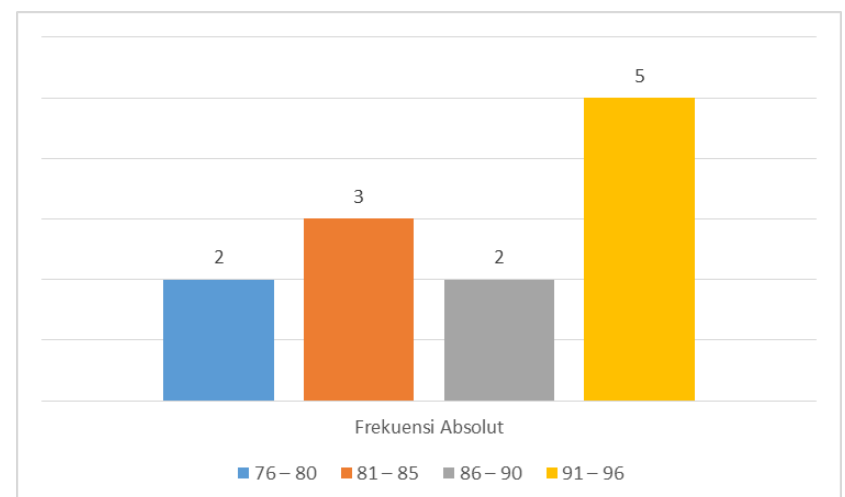

Gambar 2. Histogram Hasil Penilaian Kemampuan Guru siklus I

Kemampuan guru yang tertinggi dalam melaksanakan pembelajaran ada pada nilai 91 sampai 96, guru yang memperoleh nilai dalam rentang ini sebanyak 5 orang guru sedangkan kemampuan terendah ada pada nilai 76 sampai 80 dengan 2 orang guru yang mendapat nilai. Persentase ketuntasan pada siklus I ini adalah $41,7 \%$, belum mencapai indicator keberhasilan (minimal 80\%)

Pada siklus II dilaksanakan sesuai hasil refleksi pada siklus I, dimana dilakukan perbaikan-perbaikan berdasarkan refleksi siklus I. Berdasarkan hasil pengamatan pada siklus II diperoleh data sebagai berikut

Tabel 3. Hasil Penilaian Kemampuan Guru melaksanakan Pembelajaran Teaching factory siklus II

\begin{tabular}{ccc}
\hline No & Keterangan & Nilai \\
\hline 1 & Jumlah Nilai & 1456 \\
2 & Nilai rata-rata/kuantitatif & 94 \\
3 & Nilai Kualitatif & $\mathrm{A}$ \\
4 & Ketuntasan & 91 \\
5 & Guru yang tuntas & 11 \\
6 & Guru yang belum tuntas & 1 \\
7 & Persentase ketuntasan & $91,67 \%$ \\
\hline
\end{tabular}


ketuntasan yang diperoleh yaitu pada siklus I dari 12 orang guru produktif hanya 5 orang yang tuntas dengan persentase ketuntasan $41,7 \%$ dengan rata-rata 86 . Namun pada siklus II terjadi kenaikan kemampuan guru dalam menggunakan model pembelajaran Teaching Factory yaitu 91,67\% dengan 11 orang guru produktif yang tuntas dengan rata-rata nilai 94 dan nilai ini sudah mencapai indicator keberhasilan yang ditetapkan dalam penelitian ini.

Sebelum pengamatan dilakukan maka dilakukan workshop pada guru-guru produktif. Dalam workshop dijelaskan proses pembelajaran Teaching Factory serta berkonsultasi dengan guru-guru tentang kemampuan mereka serta memberikan bimbingan-bimbingan serta motivasi agar proses dilakukan dengan benar. Namun pelaksanaan siklus I masih terlihat beberapa kelemahan, guru mengajar pada siklus I masih belum konsisten mengikuti tahapan teaching factory. Maka kembali diajak guru-guru untuk berdiskusi, bertanya jawab baik pada saat pertemuan awal maupun pada saat mereka selesai mengajar. Kegiatan diskusi yang terus dilakukan agar menstimulir kegiatan yang dilakukan guru demi adanya perbaikan. Dengan workshop yang dilakukan ini akhirnya, kemampuan guru mulai ada peningkatan dalam melaksanakan pembelajaran pada siklus I. Siklus II dilaksanankan berdasarkan hasil refleksi di siklus I. Perbaikan dilakukan di awal sebelum guru mulai melaksanakan pembelajaran, dengan lebih menekankan untuk merubah paradigma mengajar menjadi membelajarkan siswa. Dengan guru berperan sebagai fasilitator dalam proses interaksi dalam kelas. Dalam kegiatan workshop yang dilakukan diawal ini memberikan bimbingan tentang kekurangan yang ada dan menyampaikan agar guru melaksanakan kegiatan pembelajaran seperti yang sudah tertuang dalam Rencana Pelaksanaan pembelajaran (RPP) yang dibuat. Aspek waktu juga perlu mendapat perhatian, karena itu guru perlu memeprhatikan waktu yang tertulis dalam RPP. Pemberian motivasi yang terus dilakukan pada awal pertemuan juga mampu mempenagruhi peningkatan kemampuan guru dalam melaksnakan pembelajaran Teaching Factory. Dari hasil pengamatan maka terjadi kenaikan kemampuan guru dalam melaksanakan pembelajaran dari siklus I rata-rata 86 naik menjadi 94 pada siklus II.

Kenaikan kemampuan guru produktif melaksanankan pembelajaran Teaching Factory karena adanya workshop. Workshop yang dilaksanakan berhasil meningkatkan kemampuan guru melaksnakan pembelajaran Teaching Factory. Dimana terus dilakukan diskusi yang menekankan pada kemampuan melaksnakan pembelajaran Teaching Factory. Hal ini senada dengan penelitian yang dilakukan oleh Osnal dkk [8], bahwa adanya pengaruh positif workshop terhadap kemampuan guru. Penelitian dari Sutono [10] juga menyatakan bahwa setelah penerapan workshop maka adanya peningkatan kemampuan pemahaman teoritis/konseptual guru dalam pembelajaran. Selain itu Pembelajaran Teaching Factory sangat cocok diterapkan di SMK seperti yang disampaikan Siswanto [11] bahwa Teaching Factory dapat memberikan kontribusi dalam peningkatan kompetensi siswa
SMK dengan cara memberikan hasil luaran yang memiliki kulaitas baik.

\section{KESIMPULAN}

Workshop yang dilakukan dalam melaksanakan pembelajaran Teaching Factory dapat meningkatkan kemampuan guru. Data hasil penelitian pada siklus I nilai rata-rata 86 (B) dan persentase ketuntasan $41,7 \%$. Data pada siklus II mengalami kenaikan dengan rata-rata 94 (A) dan persentase ketuntasan 91,67\%. Dengan demikian workshop dapat meningkatkan kemampuan guru produktif di SMK Negeri 7 Palu dalam melaksnakan pembelajaran Teaching Factory.

\section{REFFERENSI}

[1] L. N. Kamamia, N. T. Ngugi, \& R. W. Thinguri, "To establish the extent to which the subject mastery enhances quality teaching to student-teachers during teaching practice," International Journal of Education and Research, 2(7), 2014, pp. 641-648.

[2] Uno, B. Hamzah, "Model Pembelajaran Menciptakan Proses Belajar Mengajar yang Kreatif dan Efektif," Jakarta: Bumi Aksara, 2007.

[3] A. F. Amar, D. Hidayat, A. Suherman, "Penerapan Model Pembelajaran Teaching factory 6 Langkah (model TF6M) Untuk Meningkatkan Motivasi Berprestasi siswa di SMK," Journla of Mechanical Engineering Education. 2(2), 2015, pp. $189-198$.

[4] N. Fajaryati, "Evaluasi Pelaksanaan Teaching Factory SMK Di Surakarta," Jurnal Pendidikan Vokasi, 2(3), 2012.

[5] D. H. Martawijaya, "Developing a teaching factory learning model to improve production competencies among mechanical engineering students in a vocational senior high school," Journal of Technical Education and Training (JTET), 4(2), 2012, pp. 45-56.

[6] Gomes, F. Cardoso, "Manajemen Sumber Daya Manusia," Jakarta: Andi Offset, 2003.

[7] T. Sudiati, "Peningkatan Kinerja Guru Dalam Menetapkan Kriteria, Ketuntasan Minimal Melalui Workshop," Jurnal Kajian Teori dan Praktik Kependidikan. 3 (2), 2018, pp. 235-236

[8] Osnal, Suhartini, I. Wahyudi, "Meningkatkan Kemampuan Guru dalam Menyusun Tes Hasil Belajar Akhir Semester melalui Workshop di KKG gugus 02 Kecamatan Sumber Malang Tahun pelajaran 2014/2015, 5(1), 2016, pp. $67-82$.

[9] Gazali, A. Dardiri, S. Soekopitojo, "Penerapan Teaching Factory Jasa Boga untuk Meningkatkan Kompetensi 
Entrepreneur Siswa Sekolah Menengah Kejuruan," Jurnal Sosial Humaniora dan Pendidikan. 2 (1), 2017.

[10]E. Sutono, "Peningkatan Kompetensi guru SD dalam perancangan RPP dengan pendekatan Saintifik Melaui Workshop," Lembaran Ilmu Pendidikan, 4(2), 2017, pp. $81-94$

[11]I. Siswanto, "Pelaksanaan Teaching Factory untuk Meningkatkan Kompetensi dan Jiwa Kewirausahaan Siswa Sekolah Menengah Kejuruan," Seminar Nasional 2011 "Wonderful Indonesia," Yogyakarta. 2011, pp. 396-404. 